Jurnal Ilmu Ilmu Agribisnis: Journal of Agribusiness Science, 9(2), Mei 2021

\title{
SISTEM REPLANTING KELAPA SAWIT, OPPORTUNITY PENDAPATAN KELAPA SAWIT DAN TINGKAT KESEJAHTERAAN PETANI PADA MASA REPLANTING DI PERKEBUNAN KELAPA SAWIT RAKYAT KABUPATEN LAMPUNG TENGAH
}

\author{
(Oil Palm Replanting System, Income Opportunity and Welfare Level of Oil Palm Farmers During \\ Replanting at Oil Palm Populace Estate in Central Lampung Regency) \\ Ria Kurniasih, Raden Hanung Ismono, Teguh Endaryanto
}

\begin{abstract}
Jurusan Agribisnis, Fakultas Pertanian, Universitas Lampung, Jl. Prof. Dr. Soemantri Brojonegoro No. 1 Bandar Lampung 35145, e-mail : hanung.ismono@fp.unila.ac.id
\end{abstract}

\begin{abstract}
This study aims were to determine the replanting model used by oil palm farmers, to calculate the replanting cost, to know the opportunity lost income, and to analyze the level of welfare of farmers during replanting in Central Lampung Regency. The sampling technique was a survey. The study was conducted in three districts, Anak Tuha District, Bangun Rejo District, and Sendang Agung District. The respondents were 31 oil palm farmers consisting of 6 respondents from Anak Tuha District, 21 respondents from Bangun Rejo District, and 4 respondents from Sendang Agung District. The data collection was carried out in MarchMay 2019. The results showed tha the replanting model used by oil palm farmers in Central Lampung Regency was the intercropping model with food crops and the underplanting model. The costs of replanting during the first 3 years when the palm trees are not productive yet were IDR45,481,990 per hectare on the intercropping model and IDR 48,146,117 per hectare on the underplanting model. The average value of oil palm opportunity lost income the intercropping model with food crops was IDR7,672,043 per hectare. The average household income of oil palm farmers was IDR19,489,145 per year. The level of welfare of farmers during replanting in Central Lampung Regency in general is in a fairly decent condition.
\end{abstract}

Key words: cost, income, oil palm, opportunity, replanting, welfare

\section{PENDAHULUAN}

Indonesia adalah negara agraris yang memiliki potensi dan kontribusi yang besar terhadap pembangunan ekonomi nasional. Hal ini terlihat dari sebagian besar masyarakat Indonesia bekerja di sektor pertanian. Sektor pertanian berperan dan berkontribusi dalam penyedia bahan pangan dan bahan baku industri, penyumbang Produk Domestik Bruto (PDB), penghasil devisa negara, penyerap tenaga kerja, dan sumber utama pendapatan rumah tangga. Sektor pertanian terdiri dari subsektor peternakan, perkebunan, pangan, perikanan, dan kehutanan. Subsektor yang paling diunggulkan yaitu subsektor perkebunan. Provinsi Lampung adalah salah satu provinsi yang mengembangkan komoditas perkebunan.

Sawit adalah salah satu jenis tanaman perkebunan yang menghasilkan minyak makanan, minyak industri, maupun bahan bakar nabati (biodiesel). Dengan bergulirnya waktu dalam pengembangan kelapa sawit, ternyata beberapa wilayah pengembangan sudah memasuki ambang ekonomis dan harus melakukan peremajaan tanaman kelapa sawit atau replanting. Namun demikian yang harus dicermati yaitu terjadinya kehilangan pendapatan pada periode TBM dan biaya peremajaan yang cukup tinggi (Risman dan Iskamto, 2018). Menurut Badan Pusat Statistika Provinsi Lampung (2018), Kabupaten Lampung Tengah merupakan kabupaten dengan produksi tertinggi kelapa sawit yaitu sebesar 43.279 ton dengan luas areal sebesar 19.149 ha. Posisi kedua yaitu Kabupaten Tulang Bawang dengan produksi sebesar 35.981 ton dan luas areal sebesar 18.827 ha. Posisi ketiga yaitu Kabupaten Mesuji dengan produksi 23.894 ton dan luas areal 21.243 ha. Kabupaten Mesuji memiliki luas areal terbesar di Provinsi Lampung.

Kondisi usaha perkebunan kelapa sawit rakyat pada tahun 2018 di Kabupaten Lampung Tengah memiliki umur rata-rata tanaman kelapa sawit 23 tahun atau penanaman rata-rata di tahun 1995 (BP3K, 2018). Peremajaan telah dilakukan tetapi hanya sebagian kecil petani kelapa sawit saja. Berdasarkan definisi Kementerian Pertanian (2017), peremajaan merupakan upaya pengembangan perkebunan dengan melakukan penggantian tanaman tua atau tidak produktif dengan tanaman 
baru, baik secara keseluruhan maupun secara bertahap.

Secara umum, teknik replanting kelapa sawit terdiri dari tanam ulang total (TUT), tanam ulang bertahap (TUB) underplanting, tanam ulang bertahap (TUB) interplanting, intercropping dengan tanaman pangan pada masa vegetatif dan intercropping dengan tanaman tahunan selama siklus tanaman. Sementara di Kabupaten Lampung Tengah diketahui bahwa petani yang melakukan replanting kelapa sawit menerapkan dua teknik replanting yaitu teknik tanaman ulang bertahap underplanting dan teknik intercropping dengan tanaman pangan.

Jika kebun kelapa sawit petani diremajakan (replanting) para petani kelapa sawit akan kehilangan pendapatan utamanya selama tanaman belum menghasilkan. Pada masa tidak produksi ini petani harus tetap mengeluarkan biaya untuk hidup keluarga. Oleh karena itu petani harus hidup berhemat untuk tetap dapat memenuhi kebutuhan hidup (Saputri dan Syafrizal, 2018).

Berdasarkan permasalahan yang telah dijelaskan, maka perlu dilakukan penelitian terkait sistem replanting kelapa sawit, opportunity pendapatan yang hilang, sumber-sumber pendapatan petani dan tingkat kesejahteraan petani pada masa replanting di Kabupaten Lampung Tengah. Oleh karena itu tujuan penelitian adalah mengetahui teknik replanting yang digunakan oleh petani kelapa sawit serta biayanya, opportunity pendapatan yang hilang, sumber-sumber pendapatan petani replanting kelapa sawit dan tingkat kesejahteraan petani pada masa replanting di Kabupaten Lampung Tengah

\section{METODE PENELITIAN}

Metode penelitian yang digunakan pada penelitian ini adalah menggunakan metode survei. Penelitian dilakukan di Kabupaten Lampung Tengah yaitu pada tiga kecamatan diantaranya Kecamatan Anak Tuha, Kecamatan Bangun Rejo dan Kecamatan Sendang Agung. Sampel diambil seluruhnya dari tiga kecamatan tersebut. Responden penelitian adalah petani kelapa sawit yang melakukan replanting, sehingga didapatkan 31 responden terdiri dari 6 petani di Kecamatan Anak Tuha, 21 petani di Kecamatan Bangun Rejo, dan 4 petani di Kecamatan Sendang Agung.

Data yang digunakan dalam penelitian ini adalah data primer dan sekunder. Teknik pengumpulan data diperoleh melalui wawancara langsung dengan petani responden menggunakan kuisioner (daftar pertanyaan) yang telah disiapkan dan pengamatan langsung. Data sekunder diambil dari lembaga atau instansi pemerintah yang berhubungan dengan penelitian ini, seperti Badan Pusat Statistik Provinsi Lampung, Balai Penyuluhan Pertanian, Perikanan, dan Kehutanan (BP3K) Kecamatan Bangun Rejo, dan pustaka lainnya yang berhubungan dengan penelitian ini.

Teknik tanam ulang intercropping dengan tanaman sela adalah peremajaan model tanaman ulang total dikombinasikan dengan intercropping (tanaman semusim sebagai tanaman sela). Menurut pandiangan (2015), Biaya replanting adalah seluruh pengeluaran yang dikeluarkan pada kegiatan replanting. Biaya input terdiri dari biaya bibit, biaya pupuk, biaya herbisida dan biaya bibit tanaman sela. Biaya tenaga kerja terdiri dari: biaya penyuntikkan kelapa sawit, biaya prunning, biaya olah lahan, biaya pembersihan lahan, biaya pembuatan lubang, biaya penanaman kelapa sawit, biaya pemupukan, biaya penyemprotan, dan biaya penyulaman. Biaya replanting dihitung setiap tahunnya sampai tahun ke tiga. Total biaya replanting di Kabupaten Lampung Tengah meliputi:

Bi Replanting = B. input + B. tenaga kerja.....(1)

Teknik underplanting adalah teknik menanam tanaman muda dibawah tanaman tua (Hakim dan Suherman, 2018). Kondisi dimana kelapa sawit tua telah disuntik, sembari menunggu kelapa sawit tua membusuk maka dilakukan penanaman kelapa sawit muda. Biaya input terdiri dari biaya bibit, biaya pupuk dan biaya herbisida. Biaya tenaga kerja terdiri dari biaya penyuntikkan kelapa sawit, biaya prunning, biaya pembersihan lahan, biaya pembuatan lubang, biaya penanaman kelapa sawit, biaya pemupukan, biaya penyemprotan dan biaya penyulaman. Komponen biaya replanting model underplanting yang dikeluarkan di Kabupaten Lampung Tengah meliputi:

Bi Replanting = B. input + B. tenaga kerja.....(2)

Opportunity pendapatan adalah pendapatan yang hilang ketika memilih salah satu alternatif pilihan. Opportunity pendapatan kelapa sawit adalah pendapatan yang hilang dari kelapa sawit yang dibongkar ketika petani memilih untuk melakukan peremajaan. Opportunity pendapatan yang hilang pada kelapa sawit hanya terjadi selama kurun waktu kurang lebih 3 tahun, sebab pada umur 3 
tahun kelapa sawit yang di replanting sudah berproduksi. Analisis pendapatan usahatani kelapa sawit merupakan selisih antara total penerimaan yang diterima dari hasil usahatani dengan total biaya produksi yang dikeluarkan. Untuk mengetahui pendapatan yang hilang petani kelapa sawit yang melakukan replanting menggunakan data dari produksi terakhir kelapa sawit tua. Berdasarkan penelitian Sinaga, Ismono dan Adawiyah (2018), pendapatan kelapa sawit dapat dihitung berdasarkan rumus Kasim (2004), yaitu:

$\mathrm{TR}=\mathrm{Y} \cdot \mathrm{Py}$.

Keterangan:

$\mathrm{TR}=$ Penerimaan total selama 1 tahun $(\mathrm{Rp})$

$\mathrm{Y}=$ Produksi terakhir kelapa sawit sebelum dilakukan pembongkaran ( $\mathrm{Kg} /$ Tahun $)$

$\mathrm{Py}=$ Harga dari hasil produksi $(\mathrm{Rp} / \mathrm{Kg})$

$\mathrm{Pd}=$ TR-Tce

Keterangan:

$\mathrm{Pd}=$ Pendapatan usahatani selama 1 tahun $(\mathrm{Rp})$

$\mathrm{TR}=$ Total penerimaan $(\mathrm{Rp})$

Tce $=$ Total biaya tunai $(\mathrm{Rp})$

Biaya tunai terdiri dari biaya tenaga kerja (pemanenan dan pengangkutan). Petani kehilangan pendapatan pada masa replanting sebesar pendapatan kelapa sawit yang dibongkar, tetapi dalam kegiatan replanting petani melakukan tumpang sari jagung dan singkong dengan kelapa sawit muda. Sehingga petani masih mendapatkan pendapatan dari jagung dan singkong tersebut.

Pendapatan rumah tangga merupakan total seluruh pendapatan suatu rumah tangga. Pendapatan tersebut diperoleh dengan menghitung selisih antara total penerimaan yang telah diterima dari hasil usaha dengan biaya produksi yang dikeluarkan dalam satu tahun. Menurut penelitian Sari, Ismono, dan Abidin (2018) pendapatan rumah tangga dihitung berdasarkan rumus Rodjak (2002), dengan rumus sebagai berikut:

$\mathrm{Prt}=\mathrm{P} 1+\mathrm{P} 2+\mathrm{P} 3$

Keterangan :

Prt $=$ Pendapatan rumah tangga $(\mathrm{Rp})$

$\mathrm{P} 1$ = Pendapatan on farm $(\mathrm{Rp})$

$\mathrm{P} 2$ = Pendapatan off farm (Rp)

$\mathrm{P} 3$ = Pendapatan non farm $(\mathrm{Rp})$
Tabel 1. Analisis kesejahteraan rumah tangga petani replanting kelapa sawit

\begin{tabular}{ll}
\hline \multicolumn{1}{c}{ Pengeluaran Kapita Setara Beras } & \multicolumn{1}{c}{ Kategori } \\
\hline$>960 \mathrm{~kg}$ setara beras/tahun & Hidup Layak \\
$481-960 \mathrm{~kg}$ setara beras/tahun & Cukup Layak \\
$321-480 \mathrm{~kg}$ setara beras/tahun & Nyaris Miskin \\
$241-320 \mathrm{~kg}$ setara beras/tahun & Miskin \\
$181-240 \mathrm{~kg}$ setara beras/tahun & Sangat Miskin \\
$180 \mathrm{~kg}$ setara beras/tahun & Paling Miskin \\
\hline Sumber: Sajogyo (1997) &
\end{tabular}

Pendapatan on farm yang dimaksud adalah on farm bukan utama, karena pendapatan utama petani adalah berasal dari usahatani kelapa sawit. Kelapa sawit sedang diremajakan sehingga pendapatan utama dari kelapa sawit tidak ada. Pendapatan rumah tangga yang dihitung merupakan pendapatan 1 tahun terakhir.

Tingkat kesejahteraan rumah tangga diukur menggunakan kriteria Sajogyo (1997), Pengeluaran rumah tangga per kapita per tahun yang kemudian dikonversikan ke dalam ukuran setara beras untuk mengukur tingkat kemiskinan rumah tangga petani. Pengeluaran rumah tangga per kapita per tahun adalah hasil bagi antara pengeluaran rumah tangga pertahun dengan jumlah tanggungan keluarga. Pengeluaran per kapita setara beras adalah hasi bagi antara pengeluaran per kapita per tahun dengan harga beras yang berlaku.

\section{HASIL DAN PEMBAHASAN}

\section{Karakteristik Responden}

Umur petani kelapa sawit yang sedang melakukan replanting berkisar antara umur 32 hingga 79 tahun. Sebagian besar petani responden berada pada kelompok umur 48 hingga 63 tahun sebesar 48,38 persen. Tingkat pedidikan sebagian besar petani kelapa sawit yang melakukan replanting masih tergolong rendah, yaitu tamat SD sebesar 64,52 persen. Sebagian besar tanggungan keluarga petani kelapa sawit yang melakukan replanting adalah sebanyak 4 orang atau sebesar 83,87 persen. Anggota keluarga tersebut memiliki kategori umur dan pendidikan yang beragam. Responden memiliki pekerjaan sampingan yang terdiri dari pedagang, buruh tani, pengrajin kayu, buruh bangunan, kepala desa, dan tengkulak. Luas lahan kelapa sawit rata-rata adalah 1,20 ha, sedangkan luas lahan bukan kelapa sawit rata-rata adalah 0,70 ha. Dimana lahan tersebut merupakan lahan sawah yang ditanami padi. 
Tabel 2. Pendapatan tanaman sela pada lahan kelapa sawit di Kabupaten Lampung Tengah

\begin{tabular}{lrrcr}
\hline \multirow{2}{*}{ Income } & \multicolumn{2}{c}{ Tahun 1 $(\mathrm{Rp} / \mathrm{Ha})$} & \multicolumn{2}{c}{ Tahun 2 $(\mathrm{Rp} / \mathrm{Ha})$} \\
\cline { 2 - 5 } & \multicolumn{1}{c}{ Jagung } & Singkong & Jagung & Singkong \\
\hline MT1 & 1.978 .631 & 3.616 .857 & 1.296 .786 & 2.121 .536 \\
MT2 & - & - & 1.350 .833 & - \\
\hline Jumlah & 1.978 .631 & 3.616 .857 & 2.647 .619 & 2.121 .536 \\
\hline
\end{tabular}

\section{Teknik Replanting Kelapa Sawit di Kabupaten Lampung Tengah}

Teknik replanting kelapa sawit yang diterapkan oleh petani di Kabupaten Lampung Tengah adalah teknik intercropping dengan tanaman sela dan teknik underplanting. Teknik intercropping dengan tanaman sela adalah teknik peremajaan dengan cara membongkar kelapa sawit tua dan mengganti dengan kelapa sawit muda, dimana kelapa sawit muda ditumpang sari dengan tanaman sela. Teknik underplanting adalah teknik peremajaan dengan cara mematikkan kelapa sawit tua, kelapa sawit muda ditanam diantara kelapa sawit tua sembari menunggu kelapa sawit tua mati. Petani yang menggunakan teknik intercropping dengan tanaman sela yaitu sebanyak 45,84 persen. Sementara petani replanting dengan teknik underplanting yaitu sebanyak 54,84 persen.

Petani memilih teknik intercropping dengan tanaman pangan dengan alasan diantaranya adalah dapat melakukan tumpang sari dengan kelapa sawit muda, sehingga membantu petani dalam pemanfaatan lahan secara maksimal serta secara ekonomi lebih menguntungkan karena dalam memenuhi kebutuhan sehari-hari petani masih mendapat penghasilan. Sementara petani yang memilih teknik underplanting, tidak mendapatkan penghasilan yang berasal dari lahan kelapa sawit, dikarenakan kelapa sawit tua sedang dalam proses pembusukkan dan kelapa sawit muda belum berproduksi. Terdapat 6,00 persen petani kelapa sawit yang memborongkan kelapa sawit tua ke pengrajin gula, dengan harga perbatang adalah Rp10.000. Pemborong memiliki kewajiban membersihkan rumput sekitar pohon kelapa sawit.

\section{Biaya Replanting Teknik Intercropping dengan Tanaman Sela}

Teknik intercropping dengan tanaman sela adalah peremajaan model tanaman ulang total di kombinasikan dengan intercropping (tanaman semusim sebagai tanaman sela). Kegiatan meliputi kegiatan pra tanam, pembongkaran sawit, pengolahan lahan, pembuatan lubang, penanaman sawit, penanaman tanaman sela, pemupukan, penyemprotan HPT, dan penyulaman kelapa sawit. Kegiatan pembongkaran kelapa sawit dengan cara disuntik menggunakan herbisida, dapat pula dengan cara ditebang menggunakan gergaji. Setelah kelapa sawit disuntik, selanjutnya dilakukan kegiatan prunning untuk membantu mempercepat kelapa sawit mati. Pemupukkan kelapa sawit muda dilakukan 3 kali dalam 1 tahun, sedangkan penyemprotan hama dan gulma bisa sampai sebanyak 6 kali dalam 1 tahun tergantung tingkat serangan hama. Petani kelapa sawit pada masa replanting mendapatkan tambahan pendapatan yang berasal dari kegiatan tanaman sela yaitu tanaman sela jagung dengan kelapa sawit muda, dan tanaman sela singkong dengan kelapa sawit muda.

Pada tahun 1 petani yang menanam tanaman sela yaitu komoditas jagung sebesar 71,00 persen dan ditanam 1 kali dalam 1 tahun, sementara petani yang menanam singkong sebesar 28,00 persen dan ditanam 1 kali dalam 1 tahun. Pada tahun 2 petani yang menanam jagung sebesar 50,00 persen dan jagung ditanam 2 kali dalam 1 tahun, sedangkan petani yang menanam singkong sebesar 14,00 persen dan ditanam 1 kali dalam 1 tahun. Kegiatan tumpang sari hanya dilakukan hingga tahun ke 2, dikarenakan pada tahun ke 3 batang kelapa sawit sudah tinggi. Total pendapatan dari kegiatan tumpang sari selama masa replanting selama 3 tahun yaitu sebesar Rp10.364.643.

Tabel 3. Rincian biaya replanting teknik intercropping dengan tanaman pangan di Kabupaten Lampung Tengah tahun 2018

\begin{tabular}{lrrr}
\hline \multirow{2}{*}{ Uraian } & \multicolumn{1}{c}{ Tahun 1 } & \multicolumn{1}{c}{ Tahun 2 } & \multicolumn{1}{c}{ Tahun 3 } \\
\cline { 2 - 4 } & Biaya (Rp) & Biaya (Rp) & Biaya (Rp) \\
\hline Pra Tanam & 4.592 .143 & - & - \\
Usahatani Jagung & 4.466 .929 & - & - \\
\hline Biaya Pra Tanam & 9.059 .071 & - & \\
\hline Biaya Replanting & & & \\
Bibit & & & - \\
$\quad$ Bibit awal & 5.014 .350 & & \\
$\quad$ Bibit Sulam & 1.370 .589 & 275.560 & \\
Pupuk & & & \\
$\quad$ Kandang & 316.566 & 408.281 & \\
$\quad$ Urea & 441.000 & 558.000 & 392.369 \\
$\quad$ NPK & 572.000 & 543.900 & 353.457 \\
Herbisida & & & - \\
$\quad$ Gramaxone & 1.200 .458 & & \\
$\quad$ Roundup & 823.632 & 570.000 & 130.000 \\
Tenaka Kerja & 7.440 .000 & 1.980 .000 & 1.620 .000 \\
Tumpang Sari & 5.906 .765 & 6.505 .991 & - \\
\hline Total Biaya & 32.144 .431 & 10.841 .732 & 2.495 .826 \\
Replanting & & & \\
\hline
\end{tabular}


Tabel 3 menunjukkan komponen biaya yang dikeluarkan dalam kegiatan replanting kelapa sawit. Total biaya replanting untuk model intercropping adalah Rp45.481.990 per hektar selama 3 tahun. Kegiatan tumpang sari memiliki kontribusi sebesar 22,00 persen dalam menutup biaya replanting selama 3 tahun. Pada tahun 1 kegiatan replanting sangat rentan terhadap serangan hama dan penyakit, serangan hama terlihat pada 2 minggu pertama, daun kelapa sawit muda habis karena diserang kumbang tanduk.

Serangan hama terlihat pada 2 minggu pertama, daun kelapa sawit muda habis karena diserang kumbang tanduk. Hal ini yang menyebabkan tanaman kelapa sawit mati, penyulaman dilakukan ketika ada tanaman yang mati. Pada tahun 3, lahan kelapa sawit sudah tidak ditanami tanaman sela karena kondisi kelapa sawit yang sudah cukup tinggi.

\section{Biaya Replanting Teknik Underplanting}

Biaya replanting kelapa sawit pada teknik underplanting terdiri dari biaya input dan biaya tenaga kerja. Biaya input meliputi biaya bibit, biaya pupuk, dan biaya herbisida. Biaya tenaga kerja meliputi biaya penyuntikan, biaya pruning, biaya pembersihan lahan, biaya olah lahan, biaya penanaman, biaya pemupukan, penyemprotan HPT, dan biaya penyulaman. Kelapa sawit yang telah disuntik didiamkan sampai nantinya membusuk, sambil menunggu kelapa sawit busuk maka diantara kelapa sawit tua ditanami kelapa sawit muda.

Tabel 4. Rincian biaya replanting teknik underplanting di Kabupaten Lampung Tengah tahun 2018

\begin{tabular}{|c|c|c|c|}
\hline \multirow{2}{*}{ Uraian } & Tahun 1 & Tahun 2 & Tahun 3 \\
\hline & Biaya (Rp) & Biaya (Rp) & Biaya (Rp) \\
\hline \multicolumn{4}{|l|}{ Bibit } \\
\hline Bibit awal & 4.155 .260 & - & - \\
\hline Bibit Sulam & 2.101 .952 & 412.332 & - \\
\hline \multicolumn{4}{|l|}{ Pupuk } \\
\hline Kandang & 879.203 & 188.235 & 94.118 \\
\hline Urea & 1.797 .509 & 1.524.231 & 987.017 \\
\hline NPK & 1.656 .759 & 2.218 .892 & 721.008 \\
\hline \multicolumn{4}{|l|}{ Herbisida } \\
\hline Gramaxone & 1.563 .662 & 1.258 .824 & - \\
\hline Roundup & 2.291 .603 & 1.130 .667 & 337.748 \\
\hline Paratop & 970.286 & & - \\
\hline Metafuron & - & 1.493 .333 & 605.714 \\
\hline Tenaga Kerja & 16.261 .078 & 4.805 .510 & 691.176 \\
\hline Total Biaya & 31.677 .311 & 13.032 .024 & 3.436 .782 \\
\hline
\end{tabular}

Tabel 4 menunjukkan biaya replanting pada teknik underplanting adalah Rp48.146.117/ha dalam kurun waktu tiga tahun. Pada tahun 1 biaya terbesar terdapat pada biaya tenaga kerja yaitu Rp16.261.078/ha, yang terdiri dari kegiatan penyuntikkan, pruning, olah lahan, pembuatan lubang tanam, penanaman, pemupukkan, penyemprotan, dan penyulaman. Pada tahun ke 2 biaya terbesar adalah biaya tenaga kerja yaitu Rp4.805.510/ha. Pada tahun ke 3 biaya terbesar terdapat pada biaya penggunaan pupuk urea.

\section{Opportunity Pendapatan yang Hilang}

Kegiatan replanting kelapa sawit, menyebabkan petani tidak memiliki pendapatan yang berasal dari kelapa sawit karena kelapa sawit muda belum berproduksi. Ketika petani memilih untuk melakukan replanting, artinya petani sudah siap kehilangan pendapatan dari kelapa sawit tua yang dibongkar. Maka petani akan kehilangan pendapatan selama masa replanting. Pendapatan yang dikorbankan adalah sebesar pendapatan kelapa sawit sebelum di replanting.

Tabel 5 menunjukkan rata-rata pendapatan petani kelapa sawit pada produksi terakhir kelapa sawit tua sebelum melakukan replanting di Kabupaten Lampung Tengah. Petani memilih untuk melakukan pembongkaran kelapa sawit, dimana kelapa sawit yang sedang diremajaan tidak berproduksi selama kurang lebih 3 tahun. Petani kehilangan pendapatan sebesar rata-rata pendapatan kelapa sawit yang tidak dibongkar yaitu Rp6.012.229/tahun. Dengan demikian pendapatan yang dikorbankan pada masa replanting selama 3 tahun adalah Rp18.036.686/ha, dengan asumsi bahwa pendapatan terakhir kelapa sawit 3 tahun terakhir sama. Produksi rata-rata terakhir kelapa sawit adalah $11.175 \mathrm{~kg}$, dengan tingkat harga $\mathrm{Rp} 1.095$, dan biaya yang dikeluarkan Rp3.107.143. Sehingga pendapatan perluasan lahan Rp9.100.640, dan pendapatan per ha Rp6.012.229/tahun.

Tabel 5. Pendapatan per tahun petani kelapa sawit pada produksi terakhir kelapa sawit tua sebelum melakukan replanting di Kabupaten Lampung Tengah

\begin{tabular}{lrrr}
\hline $\begin{array}{c}\text { Teknik } \\
\text { Replanting }\end{array}$ & $\begin{array}{c}\text { Produksi } \\
(\mathrm{Kg})\end{array}$ & Penerimaan & $\begin{array}{c}\text { Pendapatan } \\
(\mathrm{Rp} / \mathrm{Ha})\end{array}$ \\
\hline Inter & 11.175 & 12.207 .783 & 6.012 .229 \\
Under & - & - & - \\
\hline
\end{tabular}


Petani mengalami kehilangan pendapatan sebesar pendapatan kelapa sawit yang dibongkar. Akan tetapi kelapa sawit yang diremajaan dengan teknik intercropping masih menghasilkan pendapatan yang berasal dari tanaman sela. Pendapatan tanaman sela pada masa replanting adalah Rp10.364.643. Pendapatan tanaman sela ini dapat mengurangi pendapatan yang hilang dari membongkar kelapa sawit. Besarnya pendapatan yang hilang dikurangi pendapatan tanaman sela adalah Rp7.672.043. Dengan demikian pendapatan yang hilang pada masa replanting selama kurun waktu 3 tahun adalah Rp7.672.043.

Ketika petani tetap melanjutkan merawat kelapa sawit yang ada, tentu dalam kurun waktu yang panjang produksi kelapa sawit akan semakin menurun, sedangkan ketika petani memilih untuk melakukan pembongkaran atau peremajaan, petani akan mengalami kehilangan pendapatan selama masa replanting, kelapa sawit muda belum menghasilkan yaitu selama kurun waktu 3 tahun. Setelah tanaman kelapa sawit menghasilkan, pendapatan petani tentu akan naik dan akan bertahan dalam kurun waktu yang panjang.

\section{Sumber-Sumber Pendapatan Rumah Tangga}

Tingkat pendapatan rumah tangga berpengaruh terhadap tingkat kesejahteraan rumah tangga. Di mana apabila pendapatan rumah tangga semakin tinggi, maka semakin tinggi pula kemampuan petani dalam memenuhi hidupnya, dan pengeluaran rumah tangga juga akan semakin tinggi, begitupun sebaliknya. Sehingga rumah tangga dengan pendapatan yang tinggi cenderung lebih sejahtera dibandingkan dengan dengan rumah tangga yang berpendapatan kecil. Sumber pendapatan rumah tangga berasal dari pendapatan on farm (kegiatan budidaya), off farm, dan non farm. Pendapatan on farm terdiri dari usahatani padi, tanaman sela, dan ternak. Pendapatan off farm terdiri dari buruh tani dan pengempul gabah. Pendapatan non farm terdiri dari tukang, pedagang dan kepala dusun.

Tabel 6. Pendapatan on farm petani replanting kelapa sawit dalam 1 tahun

\begin{tabular}{lcr}
\hline \multicolumn{1}{c}{ Sumber Pendapatan } & $\begin{array}{c}\text { Rata-rata } \\
\text { Pendapatan (Rp/Ha) }\end{array}$ & \multicolumn{1}{c}{$\%$} \\
\hline Padi & 5.534 .677 & 43,00 \\
Tanaman sela jagung & 1.195 .699 & 9,00 \\
Tanaman sela singkong & 958.113 & 7,00 \\
Ternak & 5.041 .935 & 39,00 \\
\hline Total & 12.730 .403 & 100,00 \\
\hline
\end{tabular}

Tabel 7. Total pendapatan rumah tangga dalam 1 tahun petani replanting di Kabupaten Lampung Tengah.

\begin{tabular}{lcr}
\hline \multicolumn{1}{c}{ Jenis Pendapatan } & $\begin{array}{c}\text { Rata-rata Pendapatan } \\
(\mathrm{Rp})\end{array}$ & \multicolumn{1}{c}{$\%$} \\
\hline On farm & 12.730 .403 & 65,00 \\
Off farm & & \\
Buruh tani & 2.154 .839 & 11,00 \\
Pengempul gabah & 483.871 & 2,00 \\
Non farm & & \\
Pengrajin kayu & 870.968 & 4,00 \\
Pedagang & 2.548 .387 & 13,00 \\
Kuli bangunan & 322.581 & 1,00 \\
$\quad$ Kepala dusun & 387.097 & 2,00 \\
\hline Total Pendapatan & 19.489 .145 & 100,00 \\
\hline
\end{tabular}

Tabel 6 menunjukkan kontribusi pendapatan dari kegiatan usahatani. Kegiatan usahatani padi memiliki kontribusi 43,00 persen, ternak memiliki kontribusi 39,00 persen, sementara pendapatan tanaman sela jagung dan singkong memiliki kontribusi sebesar 16,00 persen. Kegiatan on farm memiliki kontribusi yaitu 65,00 persen dari seluruh pendapatan rumah tangga.

Tabel 7 menunjukkan total pendapatan rumah tangga petani replanting kelapa sawit, dimana pendapatan per tahun Rp19.489.145. Dengan pendapatan tersebut petani petani dapat memenuhi kebutuhan sehari-hari.

\section{Analisis Kesejahteraan Rumah Tangga Petani Kelapa Sawit}

Pengeluaran rumah tangga per kapita per tahun adalah total pengeluaran rumah tangga petani baik pengeluaran pangan maupun non pangan dalam satu tahun. Pengeluaran rumah tangga petani kelapa sawit yang sedang melakukan peremajaan adalah pengeluaran pokok rumah tangga saja, tidak termasuk pengeluaran untuk usahatani lainnya. Sehingga biaya untuk kegiatan replanting tidak termasuk kedalam pengeluaran rumah tangga. Pengeluaran rumah tangga per kapitan per tahun adalah total pengeluaran rumah tangga petani baik pengeluaran pangan maupun non pangan dalam satu tahun dan dibagi dengan jumlah anggota keluarga.

Pengeluaran rumah tangga untuk kebutuhan pangan lebih besar dibanding dengan pengeluaran non pangan, hal ini sejalan dengan penelitian Handayani, Sayekti, dan Ismono (2019) menunjukkan bahwa petani lebih mengutamakan pemenuhan kebutuan pangan. Serta, terdapat dua variabel yang berpengaruh terhadap konsumsi pangan rumah tangga. 
Tabel 8. Rata-rata pengeluaran pangan dan non pangan rumah tangga petani replanting dalam 1 tahun di Kabupaten Lampung Tengah

\begin{tabular}{|c|c|c|}
\hline Jenis Pengeluaran & Total (Rp) & $\%$ \\
\hline \multicolumn{3}{|l|}{ Pangan } \\
\hline Pangan pokok & 3.317 .283 & 15,80 \\
\hline Umbi-umbian & 183.290 & 0,90 \\
\hline Minyak dan lemak & 470.097 & 2,20 \\
\hline Pangan hewani & 1.260 .129 & 6,00 \\
\hline Pangan nabati & 622.000 & 2,90 \\
\hline Buah dan biji berminyak & 100.355 & 0,50 \\
\hline Kacang-kacangan & 35.294 & 0,20 \\
\hline Bumbu-bumbuan & 1.488 .452 & 7,00 \\
\hline Gula & 776.677 & 3,70 \\
\hline Sayur berwarna & 642.516 & 3,10 \\
\hline Sayur tidak berwarna & 17.516 & 0,10 \\
\hline Buah & 366.065 & 1,70 \\
\hline Minuman & 519.968 & 2,50 \\
\hline Lainnya & 60.129 & 0,30 \\
\hline Total Pengeluaran Pangan & 9.790 .638 & 51,90 \\
\hline \multicolumn{3}{|l|}{ Nonpangan } \\
\hline Kesehatan & 85.806 & 0,40 \\
\hline Pendidikan & 3.724 .032 & 17,70 \\
\hline Listrik & 1.086 .613 & 5,20 \\
\hline Telepon dan komunikasi & 738.387 & 3,50 \\
\hline Pakaian dan aksesoris & 224.839 & 1,10 \\
\hline Barang dan jasa & 1.061 .194 & 5,10 \\
\hline Bahan bakar & 1.178 .065 & 5,60 \\
\hline Sosial & 304.839 & 1,50 \\
\hline Pajak & 235.032 & 1,10 \\
\hline Kebersihan badan & 995.935 & 4,80 \\
\hline Kosmetik & 507.065 & 2,40 \\
\hline Total Pengeluaran Nonpangan & 9.080 .612 & 48,10 \\
\hline Total Seluruh Pengeluaran & 18.871 .250 & 100,0 \\
\hline Rumah Tangga & & 0 \\
\hline
\end{tabular}

Yaitu variabel pendapatan dan variabel jumlah anggota keluarga di Kabupaten Pesawaran. Pendapatan merupakan cermin dari daya beli sehingga kualitas dan kuantitas barang yang dibeli tergantung daya beli. Pengeluaran rumah tangga per kapita per tahun diperoleh dari menghitung pengeluaran rumah tangga selama satu tahun dibagi dengan jumlah tanggungan keluarga.

Tabel 8 menunjukkan pengeluaran rata-rata petani replanting kelapa sawit adalah $\mathrm{Rp} 18.871 .250$, dengan total pengeluaran pangan Rp9.790.638 dengan persentase 51,90 persen, dan pengeluaran non pangan Rp9.080.612 dengan persentase 48,10 persen. Hal ini berarti bahwa petani responden lebih mengutamakan untuk memenuhi kebutuhan pangan terlebih dahulu dibandingkan kebutuhan nonpangan.

Pengeluaran per tahun Rp18.871.250, dengan ratarata tanggungan keluarga adalah 4 orang, sehingga pengeluaran per kapita adalah Rp4.717.812. Pengeluaran per kapita per tahun kemudian disetarakan dengan harga beras per $\mathrm{kg}$, dimana rata-rata harga beras per kg adalah Rp9.000. Ratarata pengeluaran perkapita per tahun setara beras petani replanting kelapa sawit di Kabupaten Lampung Tengah adalah 524,20 dan berdasarkan konsep Sajogyo (1997) berada dalam kategori cukup layak. Hal ini sejalan dengan penelitian Lalita, Ismono, dan Prasmatiwi (2019) menunjukkan tingkat kesejahteraan rumah tangga petani kelapa sawit di Kabupaten Tulang Bawang dalam kondisi tidak miskin.

Kondisi petani kelapa sawit yang sedang melakukan replanting masih terbilang sejahtera atau hidup layak, walaupun pada kondisi kenyataannya sawit yang diremajaan belum menghasilkan sehingga tidak ada pendapatan untuk kelapa sawit. Dengan pendapatan yang ada petani dapat mengatur pengeluaran sedemikian rupa sehingga pada saat ini kondisi petani adalah hidup cukup layak.

\section{KESIMPULAN}

Teknik replanting yang digunakan oleh petani kelapa sawit di Kabupaten Lampung Tengah adalah teknik intercropping dengan tanaman sela dan teknik underplanting. Biaya replaning teknik intercropping adalah Rp45.481.990 per hektar selama 3 tahun, sementara teknik underplanting adalah Rp48.146.117 per hektar selama 3 tahun. Nilai rata-rata opportunity pendapatan yang hilang adalah Rp7.672.043 per hektar selama 3 tahun nilai ini didapat dari mengurangkan pendapatan terakhir kelapa sawit sebelum dibongkar dengan pendapatan tanaman sela. Sumber-sumber pendapatan rumah tangga petani kelapa sawit di Kabupaten Lampung Tengah adalah berasal dari pendapatan on farm, off farm, non farm berasal dari kegiatan berdagang, tukang dan menjadi kadus. Tingkat kesejahteraan petani pada masa replanting, petani kelapa sawit yang melakukan peremajaan di Kabupaten Lampung Tengah secara umum berada dalam kondisi cukup layak.

\section{DAFTAR PUSTAKA}

Badan Pusat Statistika. 2018. Provinsi Lampung Dalam Angka 2017. BPS Provinsi Lampung. Bandar Lampung.

Balai Penyuluhan Pertanian Perikanan dan Kehutanan. 2018. Perkebunan Kelapa Sawit. BP3K Bangun Rejo. Lampung Tengah.

Hakim M dan Suherman C. 2018. Replanting Kelapa Sawit. Penebar Swadaya. Jakarta.

Handayani M, Sayekti WD, dan Ismono RH. 2019. Konsumsi pangan rumah tangga pada desa pelaksana dan bukan pelaksana program 
percepatan keanekaragaman konsumsi pangan di Kabupaten Pringsewu. Jurnal Ilmu Ilmu Agribisnis, 7(1):28-35. https://jurnal.fp.unila.ac.id./index.php/JIA/arti cle/view/3328/2549. [21 Septem ber 2019].

Kasim S. 2004. Petunjuk Menghitung Keuntungan dan Pendapatan Usahatani. Universitas Lambung Mangkurat. Banjar baru.

Kementerian Pertanian. 2017. Pedoman Peremajaan Tanaman Kelapa Sawit pekebun. Direktorat Jendral Perkebunan RI. Jakarta. https://www.bpdp.or.id/id/peraturan/pedoman -peremajaan-perkebunan-kelapa-sawit-rakyat/. [12 Desember 2018].

Lalita R, Ismono RH, dan Prasmatiwi FE. 2019. Kajian sosial ekonomi dan tingkat kesejahteraan rumah tangga petani kelapa sawit di Kabupaten Tulang Bawang. Jurnal Ilmu Ilmu Agribisnis, 7(2):195-202. https://jurnal.fp.unila.ac.id./inde x.php/JIA/article/view/3381/2582. September 2019].

Pandiangan AK. 2015. Kajian biaya replanting tanaman kelapa sawit dengan sistem pencincangan batang di Kebun Unit II Afdeling Pondok Seng PT. Mopoli Jaya. Sekolah Tinggi Ilmu Pertanian. Medan. https://pustaka.stipap.ac.id/files/ta/11011008_ 170710104727_Full_Paper.pdf. [8 Desember 2018].

Rahim A dan Hastuti RRD. 2008. Ekonomika Pertanian : Pengantar Teori dan Kasus. Penebar Swadaya. Jakarta.

Risman dan D Iskamto. (2018). Analisis program replanting kebun kelapa sawit KUD Makarti Jaya Di Desa Kumain Kecamatan Tandun Kabupaten Rokan Hulu. Jurnal Eko dan
Bisnis, 9(2):83-94. https://ekobis.stieriauakbar.ac.id/index.php/Ekobis/article/view/21 [8 Desember 2018].

Rodjak A. 2002. Manajemen Usahatani. Pustaka Giratuna. Bandung.

Sajogyo. 1997. Pembangunan Pertanian dan Pedesaan dalam Rangka Industrialisasi. Sekindo Eko Jaya. Jakarta.

Saputri E dan Syafrizal. 2018. Kesiapan petani kelapa sawit dalam menghadapi peremajaan kebun (Replanting) di Kampung Delima Jaya Kecamatan Kerinci Kanan Kabupaten Siak. JOM Fisip, 5(1):1-10. https://jom.unri.ac.id/ index.php/JOMFSIP/article/view/16499/1592 4. [10 Desember 2018].

Sari DK, Haryono D, dan Rosanti N. 2014. Analisis pendapatan dan tingkat kesejahteraan rumah tangga petani jagung di Kecamatan Natar Kabupaten Lampung Selatan. Jurnal Ilmu Ilmu Agribisnis, 2(1):64-70. http://jurnal.fp.unila.ac.id/index.php/JIA/articl e/view/562.1586. [20 September 2019].

Sari HP, Ismono RH, dan Abidin Z. 2018. Pengaruh sertifikasi kopi terhadap curahan tenaga kerja dan struktur pendapatan rumah tangga petani di Kabupaten Lampung Barat. Jurnal Ilmu Ilmu Agribisnis, 6(2):177-178. https://jurnal.fp.unila.ac.id/index.php/JIA/artic le/view/2783/2329. [1 Januari 2019].

Sinaga SMW, Ismono RH, dan Adawiyah R. Optimalisiasi pengusahaan lahan petani kelapa sawit swadaya di Kabupaten Tulang Bawang Provinsi Lampung. Jurnal Ilmu Ilmu Agribisnis, 6(4):407-414. http://jurnal.fp.unila.ac.id./index.php/JIA/artic le/view/3061/2436. [2 Maret 2019]. 